\title{
Structuring of epilithic biofilms by the caddisfly Tinodes rostocki: photosynthetic activity and photopigment distribution in and beside larval retreats
}

\author{
Peter Stief ${ }^{1}$, Georg Becker ${ }^{2, *}$ \\ ${ }^{1}$ Max Planck Institute for Marine Microbiology, Celsiusstr. 1, 28359 Bremen, Germany \\ ${ }^{2}$ Limnological River Station of the Max Planck Institute for Limnology, Damenweg 1, 36110 Schlitz, Germany
}

\begin{abstract}
Tinodes rostocki larvae (Trichoptera: Psychomyiidae) cover large proportions of stream hard substrata with retreats constructed of mineral particles and larval silk. We consider these retreats as 3-dimensional extensions of the epilithic biofilm that may possess a distinct microenvironment, community metabolism and composition. Therefore, we compared the photosynthetic/respiratory activities $\left(\mathrm{O}_{2}\right.$ and $\mathrm{pH}$ microsensors) and the photopigment composition (HPLC) of larval retreats and the surrounding epilithic biofilms. In retreats, pigment contents and photosynthetic/respiratory activities were highest in sections with a visible microphytobenthic biofilm that were mostly the older parts of the retreats. In contrast, newly constructed sections of the retreats and the surrounding epilithic biofilm had approximately 5 -fold lower values. The fucoxanthin-to-chlorophyll ratio of the retreat biofilm was high (fuco/chl $a=1.27$ ) and indicated diatom dominance, which was not evident in the surrounding epilithic biofilm (fuco/chl $a=0.15$ ). Experimental transplantation of larval retreats to microscope slides allowed microsensor measurements through the 500 to $700 \mu \mathrm{m}$-thick wall and inside the lumen. In the light, $\mathrm{O}_{2}$ concentration and $\mathrm{pH}$ values increased significantly across the wall and remained high in the lumen of the retreat, whereas in darkness $\mathrm{O}_{2}$ and $\mathrm{pH}$ depressions in both wall and lumen were moderate or even absent. Our data suggest that $T$. rostocki larvae construct and maintain retreats with a particular physico-chemical microenvironment that favours a distinct microbial community. Thereby, abundant $T$. rostocki larvae might significantly influence benthic primary production and heterotrophic metabolism in small streams.
\end{abstract}

KEY WORDS: Stream · Epilithic biofilm · Microalgae - Photosynthesis · Trichoptera · Grazing · Microsensors $\cdot$ Photopigments

\section{INTRODUCTION}

Epilithic biofilms cover solid surfaces in running waters and harbour taxonomically and functionally diverse assemblages of bacteria, microalgae, and other organisms (Lock et al. 1984, Biggs \& Smith 2002, Araya et al. 2003). Aside from abiotic factors (e.g. light, temperature, current velocity, and nutrients) biotic interactions among the organisms determine the complexity of biofilm communities (Lock 1993). Macrofaunal activities, in particular, can shape epilithic biofilms macroscopically by producing grazing tracks (Lowe \&
Hunter 1988, Becker et al. 1997) or by constructing retreats that are rapidly overgrown by microorganisms (Leff \& McArthur 1989, Bergey \& Resh 1994, Kahlert \& Baunsgaard 1999). Thus, epilithic biofilms are not organised as homogeneous microbial layers, but are rather characterised by a mosaic-like appearance. The altered geometry has major consequences for the abundance, composition, and metabolic activity of the biofilm community. In intensely grazed areas, microphytobenthic biomass may be reduced (Rosemond et al. 1993, Becker et al. 1997, Peterson et al. 2001), but productivity may be increased due to reduced compe- 
tition for light and nutrients (Lamberti \& Resh 1983). Eventually, intense and selective grazing may decrease microphytobenthic diversity and bring about a community at an early successional stage (e.g. Steinman 1996).

Animal retreats overgrown by biofilms deserve particular attention because of their distinct internal microenvironment. For instance, nutrients might be efficiently recycled within the retreats (Hasselrot 1993, Kahlert \& Baunsgaard 1999) and macrofaunal inhabitants may favour the dominance of certain taxonomic groups of microphytobenthos in their territory (Hart 1985, Hershey et al. 1988). Thereby, the metabolic activity and abundance of a few taxonomic groups can increase locally on the retreats. It can be assumed that at great animal densities these structurally and functionally distinct biofilm patches will significantly influence the carbon and nutrient dynamics of small streams. Prominent examples are the central European species of the genus Tinodes (Trichoptera: Psychomyiidae) that are abundant in a variety of aquatic habitats. The larvae build oblong, tunnel-shaped retreats on stone surfaces. These are constructed of mineral particles held together with larval silk, and measure between 3 and $7.5 \mathrm{~cm}$ in length in 5th instar larvae of different psychomyiid species (Hickin 1967). For the inhabiting larva, the retreat functions as an efficient protection against predators, desiccation, and accidental displacement by currents. Consequently, the larva spends most of its time inside the retreat and as a necessity feeds on the biofilm growing on the retreat wall rather than on the surrounding epilithic biofilm (Hasselrot 1993, Hasselrot et al. 1996). The latter observation has also been made for Tinodes rostocki, a highly abundant caddisfly in small upland streams (Becker 1993), and is congruent with the higher percentages of ingested diatoms and mineral particles in T. rostocki compared to coexisting mobile trichopteran scrapers like Agapetus fuscipes and Apatania fimbriata (Becker 1990). Between November and May, the mean length and width of the retreats of the 5th instar larvae of $T$. rostocki in the Breitenbach, Germany, measured 4.5 and $0.4 \mathrm{~cm}$, respectively $(\mathrm{n}=430$, G. Becker unpubl. data).

In this study, we addressed the following questions: Do the larval retreats of Tinodes rostocki with their 3-dimensional architecture differ significantly from the overall epilithic biofilms, e.g. concerning photosynthetic/respiratory activity and microphytobenthic community composition? Does the macroscopically visible gradient of pigmentation along the retreats mirror the longitudinal gradient of microphytobenthic activity and biomass? Do the larval retreats enclose an internal water body with a particular chemistry to which both the retreat biofilm and the larva are exposed? Conse- quently, we quantified on a microscale the photosynthetic/respiratory activities of natural retreat and epilithic biofilms with microsensors and determined their contents and relative composition of photopigments with HPLC. The distinct microenvironment of the retreat wall and lumen was investigated using retreats experimentally transplanted onto microscope slides (Hasselrot 1993), which allowed microsensor measurements in an otherwise non-observable compartment.

\section{MATERIALS AND METHODS}

Origin of animals and retreats. The Breitenbach, a first-order upland stream in central Germany, is $4.5 \mathrm{~km}$ in length and rarely exceeds $1 \mathrm{~m}$ in width. The stream is fed by several springs and is mostly not shaded by trees, flowing through a grassland valley before entering the River Fulda. The prevalent geology in the area is Bunter Sandstone and the stream is poor in dissolved nutrients and carbonate. The average $\mathrm{pH}$ is approximately 7.1 and conductivity approximately $160 \mu \mathrm{S} \mathrm{cm}^{-1}$ $\left(25^{\circ} \mathrm{C}\right)$. The long-term averages of nutrient concentrations are: orthophosphate $40 \mu \mathrm{g} \mathrm{l}^{-1}$, ammonium $20 \mu \mathrm{g}$ $\mathrm{l}^{-1}$, nitrate $0.85 \mathrm{mg} \mathrm{l}^{-1}$, silicate $4.5 \mathrm{mg} \mathrm{l}^{-1}$. The averaged concentrations of metal ions are: $\mathrm{Na}^{+} 4.5 \mathrm{mg} \mathrm{l}^{-1}, \mathrm{~K}^{+}$ $3.5 \mathrm{mg} \mathrm{l}^{-1}, \mathrm{Mg}^{++} 4.0 \mathrm{mg} \mathrm{l}^{-1}, \mathrm{Ca}^{++} 16.0 \mathrm{mg} \mathrm{l}^{-1}$ (H. H. Schmidt pers. comm.).

Retreats together with the inhabitants were sampled between November 22 and December 10, 2002, in the middle reach of the Breitenbach where stones are densely covered with larval retreats (Fig. 1) of the univoltine species at least from August till May (Becker 1993). Average water temperature during the sampling period was $7.1^{\circ} \mathrm{C}$ and underwater light intensity varied between 23 (cloudy sky) and $263 \mu \mathrm{mol}$ photons $\mathrm{m}^{-2} \mathrm{~s}^{-1}$ (clear sky).

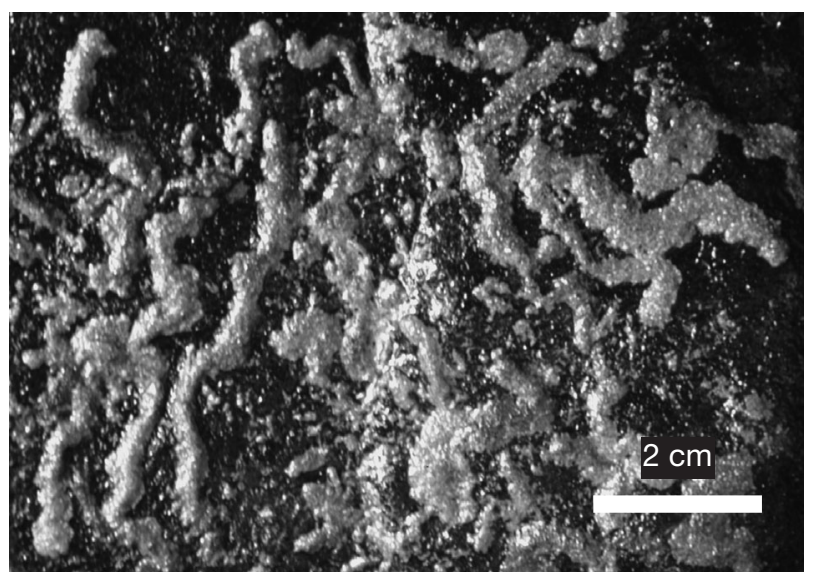

Fig. 1. Tinodes rostocki. High density of retreats on Bunter Sandstone substratum of the Breitenbach, Germany 
Preparation of retreats. We used non-manipulated retreats on freshly collected stones from the Breitenbach to compare biofilms on the retreats with those on the surrounding stone surface and to investigate the biofilm heterogeneity within the retreats ('non-transplanted retreats'). Second, we transplanted retreats taken from the Breitenbach to microscope slides, which allowed the observation of larvae and microsensors positioned inside the retreat lumen ('transplanted retreats'). For the latter approach (Hasselrot 1993), retreats and inhabitants were carefully separated from the stones and transferred to microscope slides that were submersed in a compartmented plastic box filled with stream water. Retreats of 5th instar larvae, identified by head capsule width (Becker 1993), were used for the experiments. Between 30 and $40 \%$ of the larvae attached at least a part of their retreat to the slide within $2 \mathrm{~d}$. These individuals were placed in a wheeldriven laboratory channel filled with stream water. Water temperature and light/dark cycle were adjusted to ambient field conditions and the current velocity was approximately $5 \mathrm{~cm} \mathrm{~s}^{-1}$. After several days larvae had attached the rest of the retreat to the slides and were ready for experiments. Thus, transplanted retreats have been cultured 7 to $14 \mathrm{~d}$ under laboratory conditions before they were used for experiments, while non-transplanted retreats on stones were left in the laboratory stream channel for only 2 to $48 \mathrm{~h}$ prior to the experiments.

Experimental procedure. Non-transplanted and transplanted retreats were transferred to an aquarium filled with aerated stream water with a temperature range of between 7.2 and $7.8^{\circ} \mathrm{C}$. Stones with nontransplanted retreats were lain evenly on a concrete slab that was fixed horizontally inside the aquarium about $5 \mathrm{~cm}$ below the water table. In contrast, slides with transplanted retreats were fixed in vertical position to the front window of the aquarium about $3 \mathrm{~cm}$ below the water table. Samples were illuminated at an angle of $45^{\circ}$ with a fibre-optic halogen lamp (Schott KL-1500). Underwater scalar irradiance was measured right above the samples with a quantum scalar irradiance meter (QSL 101, Biospherical). Aeration created a unidirectional water current near the retreats of 1 to $2 \mathrm{~mm} \mathrm{~s}^{-1}$ (as quantified by observing particles drifting in the water column). In this set-up photosynthetic/respiratory activities were measured with $\mathrm{O}_{2}$ and $\mathrm{pH}$ microsensors above and within the biofilms at different light intensities. Afterwards, photopigments were extracted from the biofilms of retreats and stones and analysed with HPLC.

Microsensor measurements. $\mathrm{O}_{2}$ microsensors with a tip diameter of $15 \mu \mathrm{m}$ were 2-point calibrated before use in $\mathrm{N}_{2}$-flushed and aerated stream water (0 and $100 \%$ oxygen atmospheric saturation, respectively) at
7.5 to $8.0^{\circ} \mathrm{C}$ (Revsbech 1989). $\mathrm{O}_{2}$ concentration profiles were recorded with a spatial resolution of 25 or $50 \mu \mathrm{m}$ by means of a computer-controlled micromanipulator. Positioning of the microsensor tip relative to the retreat or stone surface was accomplished by viewing sensor and sample through the aquarium wall with a dissection microscope (Leica $M$ 651). In the case of nontransplanted retreats, linear $\mathrm{O}_{2}$ gradients within the diffusive boundary layer (DBL) were measured above retreats and the stone surface. In the case of transplanted retreats, $\mathrm{O}_{2}$ profiles were recorded beginning at the centre of the retreat lumen, retreating the sensor backwards through the retreat wall, and then further backwards through the DBL surrounding the retreat. All $\mathrm{O}_{2}$ profiles were recorded after allowing adaptation to new light conditions for at least 30 and up to $120 \mathrm{~min}$ to guarantee steady state distribution of $\mathrm{O}_{2}$. The linear $\mathrm{O}_{2}$ gradient within the DBL was used to calculate the flux of $\mathrm{O}_{2}$ into or out of the sample according to Fick's law:

$$
J_{\mathrm{O}_{2}}=D_{\mathrm{s}} \times \Delta C / \Delta x
$$

where $J_{\mathrm{O}_{2}}$ is the flux of $\mathrm{O}_{2}, D_{\mathrm{s}}$ is the diffusion coefficient of $\mathrm{O}_{2}$ in water $\left(1.47 \times 10^{5} \mathrm{~cm}^{2} \mathrm{~s}^{-1}\right.$ at 7.5 to $\left.8.0^{\circ} \mathrm{C}\right)$, and $\Delta C$ is the concentration gradient across the distance $(\Delta x)$ from the surface. $J_{\mathrm{O}_{2}}$ corresponds to the net areal conversion rate of $\mathrm{O}_{2}$ of the sample. The effect of photosynthetic/respiratory activities of the biofilms on the $\mathrm{pH}$ value was measured using LIX-type $\mathrm{pH}$ microsensors with a tip diameter of 5 to $15 \mu \mathrm{m}$ (reviewed in de Beer et al. 1997). These sensors were calibrated after every third profile in standard solutions of pH 7.0 and 10.0 at 7.5 to $8.0^{\circ} \mathrm{C}$.

Non-transplanted retreats: $\mathrm{O}_{2}$ microprofiles were measured above 14 randomly chosen sections of Tinodes rostocki retreats and above 8 randomly chosen patches of stone biofilm. The 14 retreat sections were further categorised into those with a poorly developed biofilm (i.e. 8 'poor' sections) and those with a rich biofilm (i.e. 6 'rich' sections). All sampled retreats had a 'poor' section at one end and a 'rich' section at the opposite end. Within each retreat section and patch of stone biofilm the profiles were repeated 3 to 5 times.

Transplanted retreats: Microprofiles of $\mathrm{O}_{2}$ concentration and $\mathrm{pH}$ were recorded in the central part of 4 transplanted Tinodes rostocki retreats. Three retreats were inhabited by a $T$. rostocki larva, while one retreat had been left by the larva immediately prior to the measurements. Within each retreat, light intensity and parameter, the profiles were repeated 3 to 5 times. For the compartments 'external water body' (consensus distance: -1000 to $-600 \mu \mathrm{m}$ ), 'wall of retreat' (consensus distance: +200 to $+400 \mu \mathrm{m})$, and 'lumen of retreat' (consensus distance: +750 to $+1000 \mu \mathrm{m}$ ) average $\mathrm{O}_{2}$ concentrations and $\mathrm{pH}$ values were calculated. 
Photopigment analysis. After the microsensor measurements, retreats were photographed, cut into 2 to 4 longitudinal sections while still on top of the stone or slide and then cut off the surface with a scalpel and immediately frozen at $-85^{\circ} \mathrm{C}$ (Fig. 2). Biofilm covering defined areas of the stone surface was also scratched off with a scalpel and deep-frozen until further processing. Photopigments were extracted by adding $2.4 \mathrm{ml}$ of $96 \%$ cold methanol to each retreat section (Buffan-Dubau \& Carman 2000). Samples were sonicated for $20 \mathrm{~s}$ at $140 \mathrm{~W}$ with a sonication probe (Labsonic U, B. Braun) and then stored on ice for $2 \mathrm{~h}$. After centrifugation $1 \mathrm{ml}$ of the supernatant was filtered (0.45 $\mu \mathrm{m}$ Versapor membrane, Gelman Laboratory) and collected in $2 \mathrm{ml}$ vials (Zinsser Analytik). HPLC analysis was carried out with a Waters 2690 Separations Module and equipped with a PDA 996 Photodiode Array Detector (Waters). Pigments were identified according to their retention time and absorption spectrum using a library of photopigments of benthic microphytobenthos. The absolute content of the identified pigments was obtained from the peak area and the calibration curves of methanol-diluted pigment standards (Danish Hydraulic Institute). Digital in situ images of the retreats were used to determine the surface area of the retreat sections by image analysis (Nikon, Lucia G). Areal pigment contents were determined for 14 retreat sections and 4 patches of stone biofilm. To test for statistical significance of the different relative pigment composition, the mean ratio of the 2 mass pigments fucoxanthin-to-chlorophyll was calculated.

Statistical analysis. A 1-way ANOVA was used to reveal significant differences of $\mathrm{O}_{2}$ production, $\mathrm{O}_{2}$ consumption, and chl a content between the 3 sample types. A 2-way ANOVA was used to examine the influence of light intensity on oxygen atmospheric saturation and $\mathrm{pH}$ of external medium, gallery wall, and gallery lumen in transplanted retreats. For this analysis

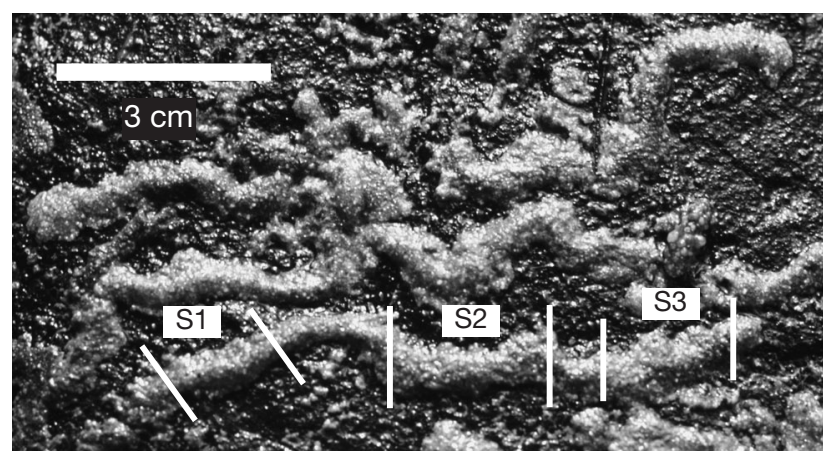

Fig. 2. Tinodes rostocki. Sections (S1-S3) of a retreat as used for pigment analysis the biofilm compartment was treated as a betweensubjects factor and light intensity as a within-subjects factor (repeated measurements in identical retreats). Pairwise post hoc comparisons were performed with Scheffé test. Differences between the fucoxanthin-tochlorophyll ratios of retreat and stone biofilms were analysed with the Mann-Whitney $U$-test. Microprofiles repeated within one retreat section or patch of stone biofilm ( 3 to 5 times) were averaged and only the average values were used for further calculations and statistical procedures. All statistical analyses were performed using the software package SPSS 12.0 (SPSS).

\section{RESULTS}

\section{Non-transplanted retreats}

Upon illumination, $\mathrm{O}_{2}$ concentrations increased towards the surface of both retreat and stone, while they decreased in the dark (Fig. 3, representative data). Fig. 4A,B summarise the averaged net $\mathrm{O}_{2}$ production and consumption rates of all analysed 'poor' and 'rich' retreat sections, and stone biofilms. $\mathrm{O}_{2}$ production rates in the light (Fig. $4 \mathrm{~A}$ ) and $\mathrm{O}_{2}$ consumption rates in the dark (Fig. 4B) were significantly higher in the 'rich' retreat sections compared to both 'poor' sections and the stone biofilms (ANOVA and Scheffé post hoc test,

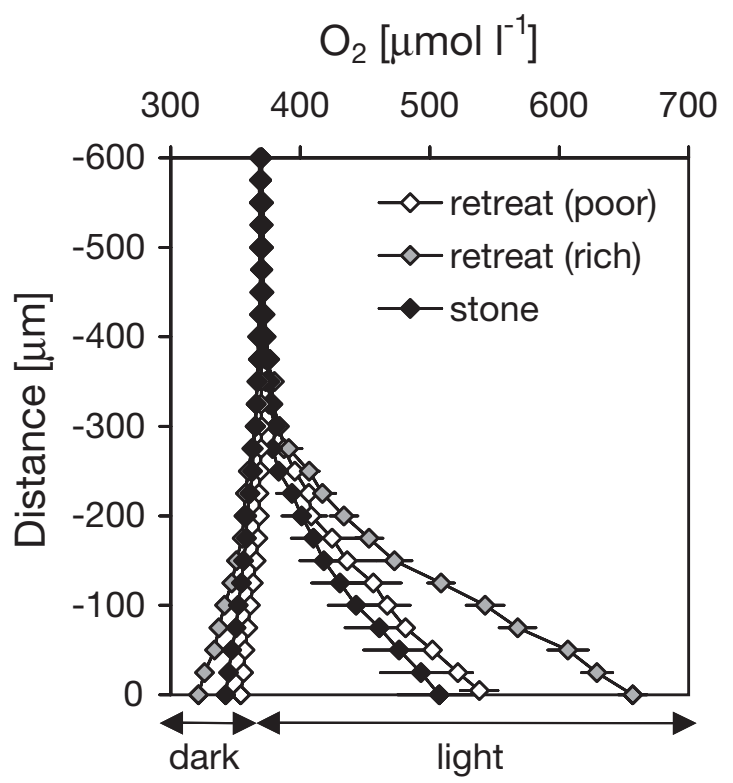

Fig. 3. $\mathrm{O}_{2}$ microdistribution above a non-transplanted retreat and a stone biofilm. 'Poor' and 'rich' indicate retreat sections with thin and thick biofilms, respectively. 'Dark' corresponds to 1 and 'light' to $200 \mu \mathrm{mol}$ photons $\mathrm{m}^{-2} \mathrm{~s}^{-1}$, respectively. Each profile represents the mean \pm SE of 3 to 4 repeated profiles recorded within $0.10 \mathrm{~cm}^{2}$. Error bars are sometimes within the symbols 


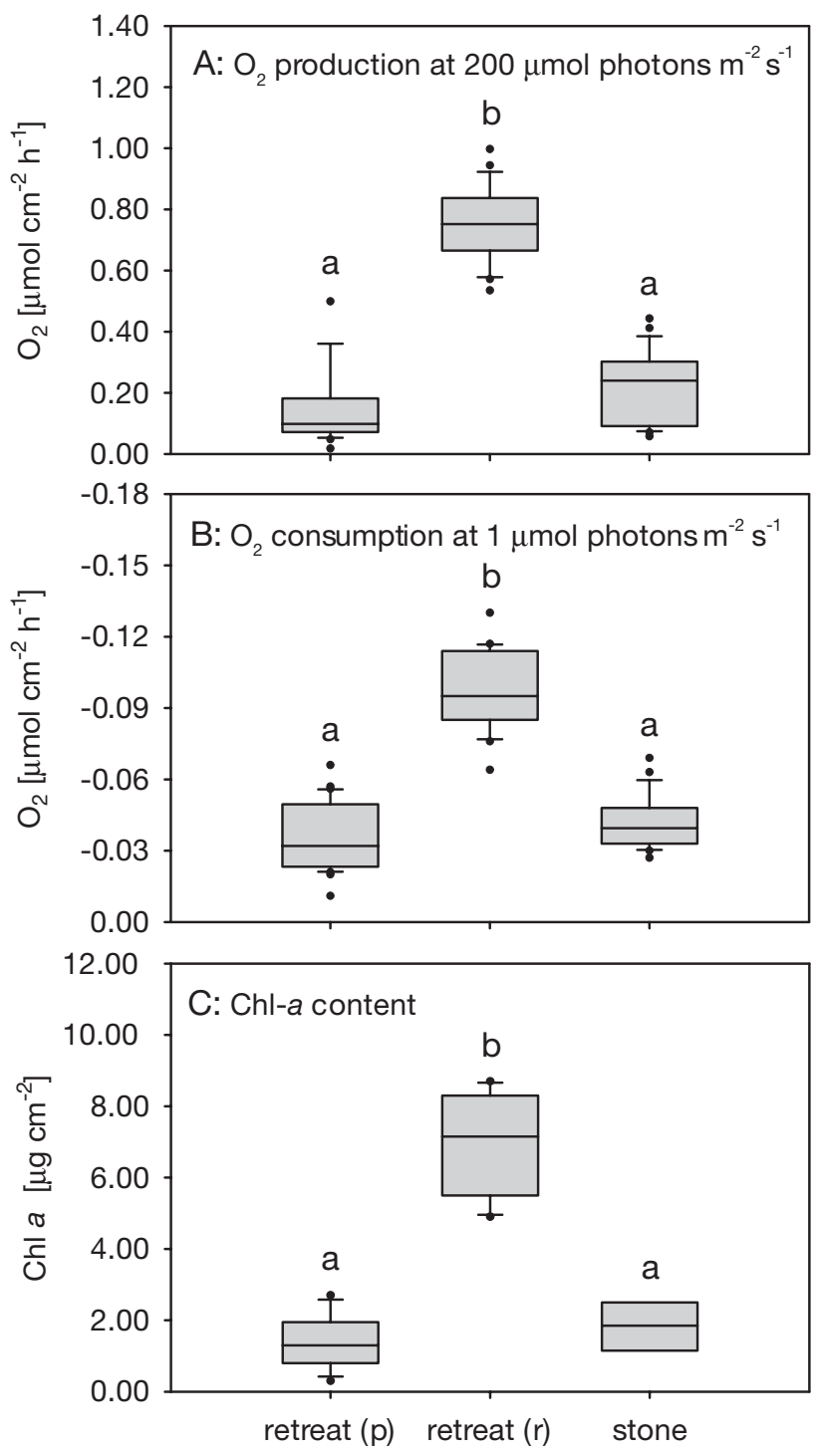

Fig. 4. (A,B) Net $\mathrm{O}_{2}$ conversion rates and $(\mathrm{C}) \mathrm{chl}$ a contents of retreat and stone biofilms. Positive rates correspond to production, negative rates to consumption of $\mathrm{O}_{2}$. Box plots give median and 1st and 3rd quartiles; whiskers give 10th and 90th percentiles; circles are outliers. Letter code shows significant differences between the medians. Whiskers are not shown for the chl a content of stone biofilms $(\mathrm{n}=4)$. Retreat $(\mathrm{p})=$ poor sections of the retreats, retreat $(r)=$ rich sections of the retreats

$\mathrm{p}<0.001)$. There was no significant difference between 'poor' retreat sections and the stone biofilms $\left(\mathrm{O}_{2}\right.$ production: $\mathrm{p}=0.552, \mathrm{O}_{2}$ consumption: $\left.\mathrm{p}=0.699\right)$.

The chl a content was significantly higher in the 'rich' than in the 'poor' sections (Fig. 4C, ANOVA and Scheffé post hoc test, $\mathrm{p}<0.01$ ). In contrast, the stone biofilm was well in the order of the 'poor' sections ( $\mathrm{p}=$ 0.955). Areal chl a content and areal $\mathrm{O}_{2}$ production at $200 \mu \mathrm{mol}$ photons $\mathrm{m}^{-2} \mathrm{~s}^{-1}$ of all sections were linearly and significantly correlated (Spearman, $\mathrm{R}^{2}=0.832$, $\mathrm{p}<$
$0.01, \mathrm{n}=18$ ). Other pigments identified in our biofilm samples were fucoxanthin and $\beta$-carotene. In the retreat biofilms chl a made up $42.0 \%$, fucoxanthin $56.5 \%$, and $\beta$-carotene $1.5 \%$ of the total pigment weight, irrespective of biofilm thickness (Fig. 5). The stone biofilm, however, was composed of $84.5 \% \mathrm{chl} a_{\text {, }}$ $10.5 \%$ fucoxanthin, and $5.0 \% \beta$-carotene (Fig. 5). The fucoxanthin-to-chlorophyll ratio of 0.15 for the stone biofilm was significantly lower than the ratio of 1.27 for the retreats (Mann-Whitney $U$-test, p < 0.001). Moreover, the fucoxanthin-to-chlorophyll ratio did not vary significantly between 'poor' and 'rich' sections of the non-transplanted retreats ( $\mathrm{p}>0.05$, data not shown).

\section{Transplanted retreats}

Upon illumination, $\mathrm{O}_{2}$ concentration and $\mathrm{pH}$ strongly increased in the DBL surrounding the retreats and were high within wall and lumen of the retreats (Fig. 6). $\mathrm{O}_{2}$ concentrations were typically elevated by

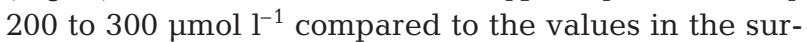
rounding medium, resulting in internal oxygen atmospheric saturations of 150 to $180 \%$ (Fig. 7A). The pH increased from 7.2 in the surrounding medium to typically $\mathrm{pH} 10$ within wall and lumen of the retreat (Fig. 7B). Profile shapes and average values within wall and lumen were close to identical at 200 and $515 \mu \mathrm{mol}$ photons $\mathrm{m}^{-2} \mathrm{~s}^{-1}$. In darkness, $\mathrm{O}_{2}$ concentrations decreased slightly in the DBL and within the retreat wall, while $\mathrm{pH}$ still increased slightly. Within wall and lumen of the retreat, $\mathrm{O}_{2}$ concentrations were

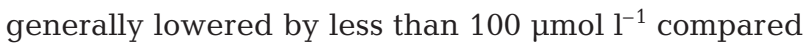
to the values in the surrounding medium, resulting in

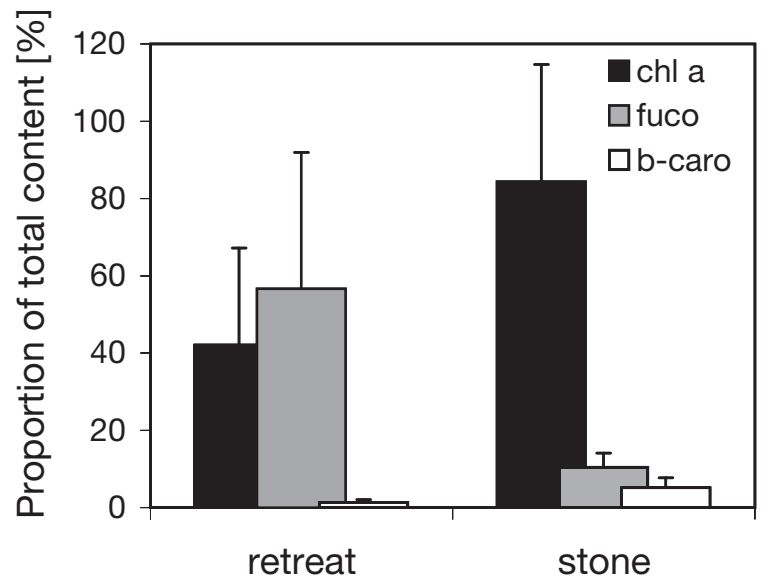

Fig. 5. Relative photopigment composition of retreat and stone biofilms. Means $\pm 1 \mathrm{SD}$ of 14 pooled retreat sections and 4 stone biofilms are shown. $\mathrm{Chl}$ a $=$ chlorophyll $a$, fuco $=$ fucoxanthin, $b$-caro $=\beta$-carotene 

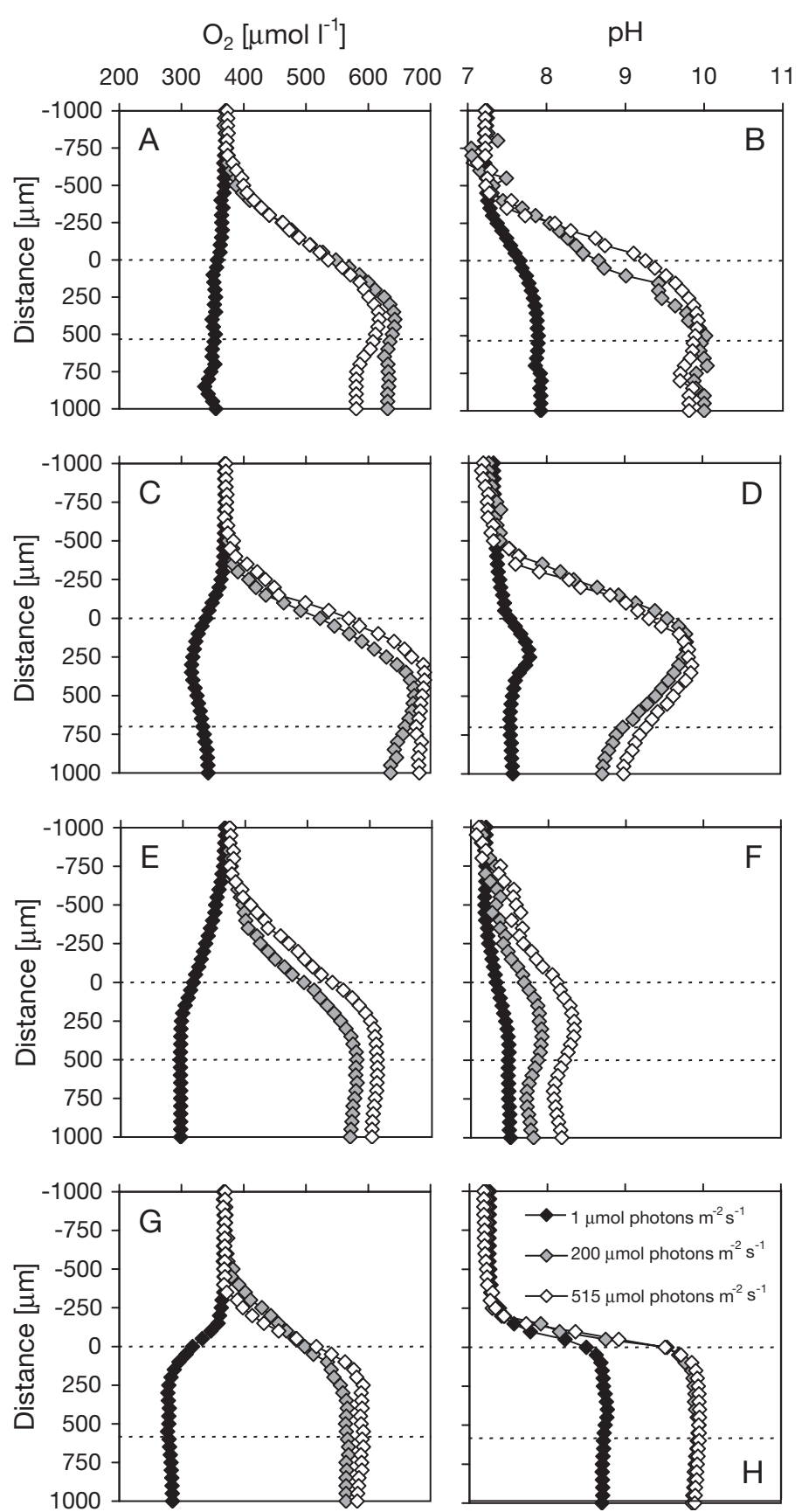

Fig. 6. $\mathrm{O}_{2}$ and $\mathrm{pH}$ microgradients around and within 4 transplanted retreats at different light intensities $(\mu \mathrm{mol}$ photons $\left.\mathrm{m}^{-2} \mathrm{~s}^{-1}\right)$. (A-F) Retreats with larva, $(\mathrm{G}, \mathrm{H})$ retreat without larva. Dashed line at $0 \mu \mathrm{m}$ delineates outer border; second dashed line delineates inner border of retreat wall. Each profile represents the mean of 3 to 5 repeated profiles recorded within $0.10 \mathrm{~cm}^{2}$

internal oxygen atmospheric saturations of always higher than $75 \%$ (Fig. 7A). The $\mathrm{pH}$ increased from 7.2 in the surrounding medium to internal values not higher than $\mathrm{pH} 8.7$ (Fig. 7B). Two-factorial ANOVA
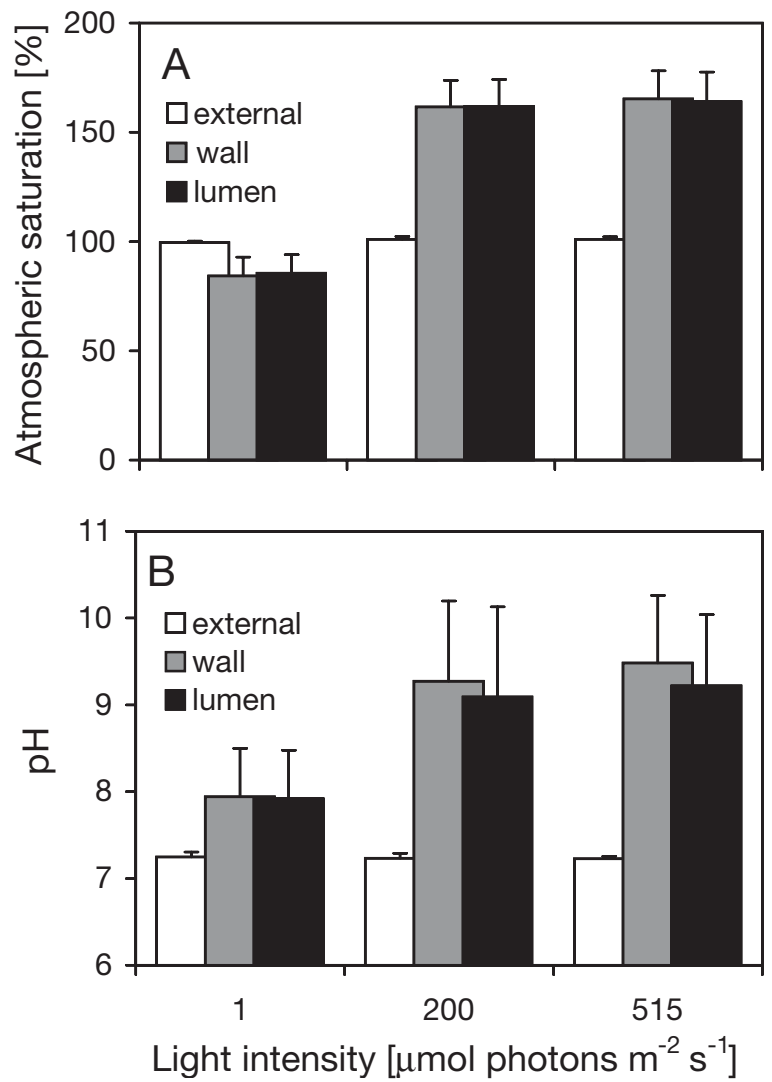

Fig. 7. (A) Oxygen atmospheric saturation and (B) pH in external medium, retreat wall, and retreat lumen measured at different light intensities in transplanted retreats. Means $\pm 1 \mathrm{SD}$ are shown for the 4 retreats presented in Fig. 6

revealed significant effects of both light intensity and biofilm compartment on oxygen atmospheric saturation and $\mathrm{pH}$ in the microenvironment of the retreats $(\mathrm{p}<0.001)$ and a significant interaction between light intensity and biofilm compartment $\left(\mathrm{O}_{2}: \mathrm{p}<0.01, \mathrm{pH}\right.$ : $\mathrm{p}<0.05$ ). Oxygen atmospheric saturation and $\mathrm{pH}$ were significantly different between both wall and lumen of the retreats and the external medium (2-way ANOVA and Scheffé post hoc test, $\left.\mathrm{O}_{2}: \mathrm{p}<0.001, \mathrm{pH}: \mathrm{p}<0.05\right)$. No significant differences were found between wall and lumen of the retreats $\left(\mathrm{O}_{2}: \mathrm{p}=0.998, \mathrm{pH}: \mathrm{p}=0.951\right)$. When a larva was present, values of both $\mathrm{O}_{2}$ and $\mathrm{pH}$ within the lumen of the gallery were somewhat lower under light conditions or higher under dark conditions than values within the wall (Fig. 6A-F). In contrast, in the absence of a larva these additional curvatures were not observed (Fig. 6G,H). The adaptation time to dark conditions (30 to $120 \mathrm{~min}$ ) was in some cases (Fig. 6B,F) not long enough to bring about the expected depression of $\mathrm{pH}$ in the wall and lumen of the retreats. Steady state conditions were probably delayed due to the buffering capacity and the limited exchange of the water volume enclosed by the retreat. 


\section{DISCUSSION}

Our combined process and structure analysis confirms earlier reports on the substantial microphytobenthic colonisation of retreats from Tinodes rostocki (Hasselrot et al. 1996) and T. waeneri (Hasselrot 1993, Kahlert \& Baunsgaard 1999). We found highest photosynthetic/respiratory activities and chl a contents in the older parts of the $T$. rostocki retreats rather than in the biofilm covering the stone surface. Moreover, the relative photopigment composition of the investigated biofilms indicated diatom dominance on the larval retreats, which was not evident in the surrounding epilithic biofilm. Therefore, at the time of our study, the biofilms of the T. rostocki retreats and the surrounding stone surface did indeed differ in terms of bulk microphytobenthic community metabolism and composition. We also found evidence that the macroscopically visible gradient of pigmentation along the retreats mirrored the longitudinal gradient of microphytobenthic activity and biomass. All sampled retreats had a lightbrown section with a low photosynthetic/respiratory activity and microphytobenthic biomass at one end and a dark-brown section with a high photosynthetic/ respiratory activity and microphytobenthic biomass at the opposite end. Only the dark-brown sections of the retreat had a higher photosynthetic/respiratory activity and microphytobenthic biomass than the stone biofilm. The structural polarity of the retreats was obviously not due to differences in bulk community structure, since the fucoxanthin-to-chlorophyll ratio did not differ between the 2 ends of the retreats. In summary, the Tinodes retreat as a whole differed from the epilithic biofilm with respect to bulk microphytobenthic community composition, but only their darkbrown ends were distinct in terms of activity and biomass. Additionally, we found indications that the wall of the retreats represents a biofilm compartment that is exposed to a microenvironment which is different from the external medium. Upon illumination, both the retreat biofilm and the inhabiting larva were exposed to $\mathrm{O}_{2}$ concentrations and $\mathrm{pH}$ values substantially higher than in the water column. We do not know, however, which conditions prevailed within the epilithic biofilm that was too thin to be probed with microsensors. In addition, we can only speculate that nutrient concentrations may also have differed between the internal and external water bodies.

The Tinodes larva constructs an oblong, tunnelshaped structure made of mineral particles held together with larval silk. The emerging formation encloses a small volume of water, the exchange of which with the external water body remains largely unknown (Hasselrot 1993, Kahlert \& Baunsgaard 1999). On the one hand, a certain isolation can be expected due to the relatively thick wall of the retreat (500 to $750 \mu \mathrm{m}$ ). On the other hand, the larvae have been observed to perform undulatory body movements that increase the exchange of water between the internal and external compartment (Hasselrot 1993, G. Becker unpubl. obs.). Our microsensor measurements indicated that upon illumination the water inside the retreat was supersaturated with $\mathrm{O}_{2}$ (150 to $180 \%$ oxygen atmospheric saturation) and highly alkaline ( $\mathrm{pH}$ 10). Comparative measurements in retreats with and without a $T$. rostocki larva revealed that water exchange between internal and external water bodies was somewhat higher when a larva was undulating in the retreat. Nevertheless we can claim that, at least in our laboratory setting, the undulatory body movements of the inhabiting larva could not fully compensate the photosynthesis-driven chemical changes inside the retreat. From this it can be speculated that part of the larval excretions may also be retained inside the retreat, which would elevate the nutrient concentrations above those of the external water body (Hershey et al. 1988, Plaganyi \& Branch 2000). Therefore, bacteria and microalgae associated with Tinodes retreats may efficiently recycle the nutrients excreted by the Tinodes larva (Kahlert \& Baunsgaard 1999). Growth may be stimulated in many or in certain species that may eventually enrich on the retreat. Preliminary studies showed high densities of the diatom Achnanthes sp. on the inside and outside of the retreat wall of T. rostocki (Hasselrot et al. 1996). In summary, both the metabolism of the retreat biofilm and larval excretions might shape the chemical microenvironment of the Tinodes retreat and consequently the activity and biomass of the associated microorganisms.

Microsensor measurements and photopigment analysis revealed a longitudinal gradient of photosynthesis (i.e. microphytobenthic activity and biomass) along the Tinodes rostocki retreat. This gradient may establish as a result of larval retreat construction and degradation. Larvae elongate their retreat on one end by affixing new mineral particles and they break down the other end in order to feed on the biofilm that is attached to the torn out particles (Hasselrot 1993, Hasselrot et al. 1996, Alecke 1998, G. Becker unpubl. obs.). The latter observation is further confirmed by the diatom dominance found in the gut of the larvae (Becker 1990), which is in accord with the diatom dominance on the retreat (Hasselrot et al. 1996). As a consequence of polar retreat elongation and degradation, an age gradient establishes which translates into a gradient of colonisation time for microalgae and bacteria. This means that the 'poor' section on one end has been recently constructed and is still poorly colonised by microorganisms, whereas the 'rich' section at the opposite end represents a densely colonised and meta- 
bolically active site of the retreat. The maximum chl a contents of 'rich' sections of T. rostocki retreats of $7.0 \pm$ $1.5 \mu \mathrm{g} \mathrm{cm}^{-2}$ (mean $\pm 1 \mathrm{SD}, \mathrm{n}=6$ ) were distinctly higher than values reported from Cox (1990) and Werneke (1997) for the epilithic biofilms of the same stretch of the Breitenbach and the same season. These authors found averaged chl a contents of between 0.5 and $2.8 \mu \mathrm{g} \mathrm{cm}^{-2}$ in November and December. The maximum values of 'rich' sections of T. rostocki retreats also exceeded the chl a contents of $T$. waeneri retreats of $2.5 \pm 0.2 \mu \mathrm{g} \mathrm{cm}^{-2}$ reported by Hasselrot (1993). The standing stock and activity of microphytobenthos of the surrounding epilithic biofilm were at the lower end of what was found on the retreats. This may result either from the better growth conditions on the retreat (see above) or from the higher overall grazing pressure on the undefended stone biofilm than on the T. rostocki territory, i.e. the retreat.

As fucoxanthin-to-chlorophyll ratios (fuco/chl a) of 0.33 to 1.65 are indicative of diatoms dominating microphytobenthic communities (Lucas \& Holligan 1999), the retreat biofilms were obviously dominated by diatoms (fuco/chl a: 1.27); this was not so for the stone biofilms (fuco/chl a: 0.15), confirming earlier observations of diatom dominance on retreats of T. rostocki as opposed to Chamaesiphon sp. (Cyanobacteria) dominance in the surrounding stone biofilm (Hasselrot et al. 1996). High abundances of diatoms on larval retreats and in grazing areas of various macroinvertebrates are commonly found in epilithic biofilms (Hart 1985, Hershey et al. 1988, Hill \& Knight 1988, Lowe \& Hunter 1988). Possible mechanisms of diatom enrichment comprise (1) the deliberate removal and disposal of unsuitable microphytobenthic species (e.g. Microcoleus vaginatus, Cyanobacteria, Hart 1985), (2) the inaccessibility of adnate diatoms compared to overstory algae (Hill \& Knight 1988), and (3) the fast recolonisation by diatomean immigrant species (Bergey 1995). In our study we have not attempted to investigate the mechanism of the diatom enrichment on the Tinodes retreat and there are no indications that one of the proposed mechanisms applies here. Instead, we can only assume that the particular architecture and microenvironment of the retreats might favour diatoms more than other groups of microphytobenthos. Owing to their unique motility, diatoms alone may benefit from both the elevated nutrient concentrations at the inside and the optimal light conditions at the outside of the retreat wall. Macroinvertebrates that are able to graze on diatoms (e.g. Trichopteran scrapers) benefit greatly from the dominance of these microalgae because of their high content of polyunsaturated fatty acids (Mayer \& Likens 1987, Steinman et al. 1987, Huryn \& Wallace 1988, Blomquist et al. 1991, Dunstan et al. 1994). In contrast, cyanobacteria are often un- manageable or even toxic for grazers (Hart 1985). In the case of $T$. rostocki, the high quality food source represented by the diatoms on the larval retreat is at the exclusive disposal of the inhabiting larva itself because it will defend the retreat obstinately against con- and heterospecific invaders (Hasselrot 1993).

At high animal densities the microbial community of epilithic biofilms might be significantly affected by the structuring impact of macroinvertebrates (e.g. animalinduced changes of the taxonomic composition, spatial organisation and metabolic activity of microorganisms). Along a $1 \mathrm{~km}$ stretch of the middle and lower reach of the Breitenbach, between 30 and $80 \%$ of the Bunter Sandstone substrata were densely covered by T. rostocki retreats (Fig. 1). Quantitative measurements showed that larval densities decreased in the course of the ontogeny from $3100 \pm 548$ larvae $\mathrm{m}^{-2}$ $($ mean $\pm \mathrm{SD}, \mathrm{n}=5)$ in October to $762 \pm 226(\mathrm{n}=5)$ in May (Becker 1993). Given the high abundance of T. rostocki (and their retreats) in small streams such as the Breitenbach, the observed differences between the stone and the retreat biofilms may have significant implications for the overall benthic primary production and its flow into the epilithic food web. A quantitative assessment of the indirect contribution of T. rostocki to benthic primary production and heterotrophic bacterial activities will become possible when the biofilms of the retreats and stone surface are investigated throughout the full period of larval development (i.e. August until May in the Breitenbach, Becker 1993).

Acknowledgements. A. Palotay-Ries and C. Möller collected Tinodes retreats in the field and determined the surface area of the retreat sections by image analysis. G. Eickert is acknowledged for constructing $\mathrm{O}_{2}$ microsensors. I. Schroeder and U. Werner performed the HPLC analysis. D. de Beer made helpful suggestions for the analysis of microsensor data. This study was supported by the Max Planck Society.

\section{LITERATURE CITED}

Alecke C (1998) Ökologie und Habitatbindung von Tinodes unicolor und Tinodes pallidulus (Trichoptera; Insecta). Ein Beitrag zur Typisierung und Bewertung von Tieflandbächen. PhD thesis, University of Münster

Araya R, Tani K, Takagi T, Yamaguchi N, Nasu M (2003) Bacterial activity and community composition in stream water and biofilm from an urban river determined by fluorescent in situ hybridization and DGGE analysis. FEMS Microbiol Ecol 43:111-119

Becker G (1990) Comparison of the dietary composition of epilithic trichopteran species in a first-order stream. Arch Hydrobiol 120:13-40

Becker G (1993) Age structure and colonization of natural substrata by the epilithic caddisfly Tinodes rostocki (Trichoptera: Psychomyiidae). Arch Hydrobiol 127:423-436

Becker G, Holfeld H, Hasselrot AT, Fiebig DM, Menzler DA (1997) Use of a microscope photometer to analyze in vivo fluorescence intensity of epilithic microalgae grown on 
artificial substrata. Appl Environ Microbiol 63:1318-1325 Bergey EA (1995) Local effects of a sedentary grazer on stream algae. Freshw Biol 33:401-409

Bergey EA, Resh VH (1994) Interactions between a stream caddisfly and the algae on its case: factors affecting algal quantity. Freshw Biol 31:153-163

Biggs BJF, Smith RA (2002) Taxonomic richness of stream benthic algae: effects of flood disturbance and nutrients. Limnol Oceanogr 47:1175-1186

Blomquist GJ, Borgeson CE, Vundla M (1991) Polyunsaturated fatty acids and eicosanoids in insects. Insect Biochem 21:99-106

Buffan-Dubau E, Carman KR (2000) Extraction of benthic microalgal pigments for HPLC analyses. Mar Ecol Prog Ser 204:293-297

Cox EJ (1990) Studies on the algae of a small soft water stream. II. Algal standing crop (measured by chlorophyll a) on soft and hard substrata. Arch Hydrobiol (Suppl) 83: 553-566

de Beer D, Schramm A, Santegoeds CM, Kühl M (1997) A nitrite microsensor for profiling environmental biofilms. Appl Environ Microbiol 63:973-977

Dunstan GA, Volkman JK, Barrett SM, Leroi JM, Jeffrey SW (1994) Essential polyunsaturated fatty-acids from 14 species of diatoms (Bacillariophyceae). Phytochemistry 35: 155-161

Hart DD (1985) Causes and consequences of territoriality in a grazing stream insect. Ecology 66:404-414

Hasselrot AT (1993) Insight into a psychomyiid life. PhD thesis, University of Uppsala

Hasselrot AT, Becker G, Holfeld H, Menzler DA, Marxsen J (1996) Strong indication for larval caddisfly gardening inside the retreat. Bulletin of the North American Benthological Society 13(1):133

Hershey AE, Hiltner AL, Hullar MAJ, Miller MC, Vestal JR, Lock MA, Rundle S, Peterson BJ (1988) Nutrient influence on a stream grazer: Orthocladius microcommunities respond to nutrient input. Ecology 69:1383-1392

Hickin NE (1967) Caddis larvae. Larvae of the British Trichoptera. Hutchinson, London

Hill WR, Knight AW (1988) Concurrent grazing effects of two stream insects on periphyton. Limnol Oceanogr 33:15-26

Huryn AD, Wallace JB (1988) Community structure of Trichoptera in a mountain stream: spatial patterns of production and functional organization. Freshw Biol 20: 141-155

Kahlert M, Baunsgaard MT (1999) Nutrient recycling-a

Editorial responsibility: Søren Rysgaard, Silkeborg, Denmark strategy of a grazer community to overcome nutrient limitation. J N Am Benthol Soc 18:363-369

Lamberti GA, Resh VH (1983) Stream periphyton and insect herbivores: an experimental study of grazing by a caddisfly population. Ecology 64:1124-1135

Leff LG, McArthur JV (1989) Microbial colonization of limnephilid caddisfly cases. Arch Hydrobiol 116:81-84

Lock MA (1993) Attached microbial communities in rivers. In: Ford TE (ed) Aquatic microbiology: an ecological approach. Blackwell, Oxford, p 113-138

Lock MA, Wallace RR, Costerton JW, Ventullo RM, Charlton SE (1984) River epilithon: toward a structural functional model. Oikos 42:10-22

Lowe RL, Hunter RD (1988) Effect of grazing by Physa integra on periphyton community structure. J N Am Benthol Soc $7: 29-36$

Lucas CH, Holligan PM (1999) Nature and ecological implications of algal pigment diversity on the Molenplaat tidal flat (Westerschelde estuary, SW Netherlands). Mar Ecol Prog Ser 180:51-64

Mayer MS, Likens GE (1987) The importance of algae in a shaded headwater stream as food for an abundant caddisfly (Trichoptera). J N Am Benthol Soc 6:262-269

Peterson CG, Horton MA, Marshall MC, Valett HM, Dahm CN (2001) Spatial and temporal variation in the influence of grazing macroinvertebrates on epilithic algae in a montane stream. Arch Hydrobiol 153:29-54

Plaganyi EE, Branch GM (2000) Does the limpet Patella cochlear fertilize its own algal garden? Mar Ecol Prog Ser 194:113-122

Revsbech NP (1989) An oxygen microsensor with a guard cathode. Limnol Oceanogr 34:474-478

Rosemond AD, Mulholland PJ, Elwood JW (1993) Top-down and bottom-up control of stream periphyton: effects of nutrients and herbivores. Ecology 74:1264-1280

Steinman AD, McIntire CD, Lowry RR (1987) Effects of herbivore type and density on chemical composition of algal assemblages in laboratory streams. J N Am Benthol Soc 6: 189-197

Steinman AD (1996) Effects of grazers on benthic freshwater algae. In: Stevenson RJ, Bothwell ML, Lowe RL (eds) Algal ecology - freshwater benthic systems. Academic Press, San Diego, p 341-373

Werneke U (1997) Freilanduntersuchungen zum Einfluß von Nahrungsangebot und Temperatur auf das Wachstum von Baetis- und Ephemerella-Arten (Insecta: Ephemeroptera). PhD thesis, University of Marburg

Submitted: July 27, 2004; Accepted: October 20, 2004 Proofs received from author(s): December 20, 2004 